Article

\title{
The Effect of Real and Virtual Construction Field Trips on Students' Perception and Career Aspiration
}

\author{
Mostafa Seifan ${ }^{1, *}$, Oluwaseun Deborah Dada ${ }^{2}$ and Aydin Berenjian ${ }^{1}$ \\ 1 School of Engineering, Faculty of Science and Engineering, The University of Waikato, Hillcrest, \\ Hamilton 3216, New Zealand; aydin.berenjian@waikato.ac.nz \\ 2 Academic Liaison Team, Library, The University of Waikato, Hillcrest, Hamilton 3216, New Zealand; \\ debby.dada@waikato.ac.nz \\ * Correspondence: mostafa.seifan@waikato.ac.nz; Tel.: +64-7-838-4173
}

Received: 15 January 2020; Accepted: 5 February 2020; Published: 7 February 2020

check for updates

\begin{abstract}
To adequately prepare students for engineering practices, it is imperative that institutions adopt innovative methods of teaching, learning, and assessment. One such approach is the use of real field trips (RFT) to construction sites, which can enhance students' perceptions of related careers. Although virtual field trips (VFTs) have emerged as a viable alternative-or supplement- to traditional field trips, little is known about their potential to provide the same or similar career exploration advantages. Using responses from a self-reported questionnaire administered to university students who participated in an RFT, this study sought to examine the usefulness of site visits in developing essential skills required for civil engineers. It also examines student perceptions on the use of VFTs as part of their university experience and the extent to which it could replace RFTs. The results indicate that students consider VFT as an enjoyable way to learn, given the possibilities facilitated by the new technology. However, notwithstanding its success, the students commonly opined that VFT was not a substitute for a RFT. From a holistic perspective, the issue is not whether VFTs can replace traditional field trips or not; it is rather the focus on identifying an integrated approach that combines lectures, and virtual and real field trips in a manner that supports a social constructivism mode of learning. Ultimately, this combination will enable students to effectively construct multiple links between lectures given in a hall and the real world outside.
\end{abstract}

Keywords: virtual field trips; real field trips; engineering careers; student perceptions; career development; construction; civil engineering; undergraduate

\section{Introduction}

Given that the field of engineering is a practical profession, traditional methods of teaching no longer meet the learning needs of students at higher levels of education. Hence, to adequately prepare students for engineering practices, it is imperative that institutions adopt innovative methods of teaching, learning, and assessment. Particularly, more importance should be placed on empowering students to make connections between theoretical concepts learnt in the classroom and applications in practice. This is particularly critical when students are introduced to huge amounts of knowledge in a short period of time, despite having no prior knowledge on the subject [1]. The limitations of adopting traditional methods of teaching-conservative lectures with direct flow of information from instructors to students-have been alluded to in the literature [2]. Although students demonstrate cognitive activeness, they are physically inactive, given the insufficient interaction between the instructor and the students [3]. This tends to produce passive learners, as students cannot maintain the required levels of rapt attention and assimilation. Although there are different factors influencing student learning and engagement in class, it has been reported that students' attention span declines after 
20-30 min [4]. A recent study also showed that attention loss starts 15-20 min after the commencement of a lecture [5]. Surprisingly, it has been reported that the greatest variability in students' attention is caused by differences between teachers, rather than teaching styles [5]. The limitations in students' abilities to assimilate information presented during class, and subsequently generate knowledge, are the main consequences of large content-specific cognitive gaps between lecturers and students [3].

To address these issues, it has been suggested that interactive activities can help provide a rich content and satisfying lecture experience for students. This could be covered in the context of sustainable teaching methods, which ensure that economic, social, and environmental resources are not overused [6]. These methods can include the usual range of classroom approaches: discussion groups, use of slides, lectures, project work, experiment, field trips, as well as online/electronic learning methods, which could function as complementary to sustainable classroom teaching. It is important to note that in order to meaningfully select from this variety of sustainable methods, the teacher needs to consider the curriculum or content to be learned. peculiarity of the students' needs, and their own abilities [6]. A key objective is ensuring that the chosen teaching methods assure consistency in delivery, that is, allowing future students to have access to similar economic, social, or environmental resources. Although this approach may have its own constraints (for example, large lecture sessions), interactive engagements can also occur through the implementation of modern creative teaching strategies and technologies $[7,8]$. Using off-piste pedagogies for teaching does not only develop students' cognitive abilities, but also encourages them to construct knowledge, instead of piling it on as is disseminated to them. Moreover, students are also encouraged to use real-world concepts to construct knowledge to solve problems. Among modern teaching methods available today, field trips (which come in different formats) and their benefits have been portrayed in several studies [9]. Regardless of the manner in which they are delivered, field trips are an important interface between teaching and learning $[10,11]$. Students appreciate field opportunities as they are exposed to different activities that increase cognition, confidence, and enjoyment during learning. Field trips can allow for active learning, as a range of constructivist and experiential instructional methods that engage student participatory activities and reflection are involved, thus helping them "learn-by-doing". A critical goal of field trips is to expose students to experiential learning. In engineering education, problem-solving skills are essential; therefore, students need to be exposed to real-world problems. The embedment of field visits can increase learning because they provide opportunities for exploration and original experiences. An understanding of the sequence or duration of activities, description of various roles linked to the project, and visualization of theoretical concepts significantly contribute to meeting predefined learning objectives [12]. However, incorporating a real field trip (RFT) in the curriculum with the overarching aim of encouraging deep learning has its own limitations. Particularly, RFTs are becoming more and more difficult to implement due to reduced budgets, concerns about safety, and increasing class sizes [11]. Also, from the school's perspective, other limitations are lack of administration support and planning issues, financial burdens to students and schools, limited choices of local sites, environmental conditions, and unwillingness of some teachers to participate. On the other hand, confidentiality of the process, equipment damage, safety matter, and the likelihood of incident/accident are the main challenges from a site perspective.

In order to compensate for increasing restrictions on field opportunities whilst still maintaining student interest, potential options that can be applied to increase field-related deep learning opportunities include the use of virtual field trips (VFTs). It has been reported that VFTs can be an alternative or complementary to field activities because they are able to simulate the realities of the "outside" world in the classroom [13]. Virtual field trips, however, vary greatly in their extent of student participation. This scope can range from low expectations from students to participate, as seen with videos and podcasts used in classroom settings, to increased expectations for student participation, as with computer-aided instruction. There are quite unlimited possibilities for the incorporation of technology as pedagogical tools of instruction in VFTs. This could range from linear and observational narratives to interactive virtual three-dimensional software-powered environments. 
Notably, the use of VFTs has increased, given advancements in technological innovations, increasing ease of use, and increasing push by decision-makers in tertiary institutions towards stronger integration of technology and pedagogy. Mead, Buxner, Bruce, et al. [14] and Agles, Burden, Tilling, et al. [15] explored new ways to teach geoscience to high school and undergraduate students using virtual environments. Pham, Dao, Pedro, et al. [16] successfully applied a 360-degree panoramic virtual reality to facilitate a Virtual Field Trip System (VIFITS) for mobile construction safety education. Jacobson, Militello and Baveye, et al. [17] also reported the development of a series of VFTs to sites around the world with the view to present students with complicated real-world situations, with which to learn critical analysis skills. Jolley, Kennedy, Reyna, et al. [18] developed a VFT for tertiary students in an introductory-level geology course at the University of Canterbury. In a recent study [19], a virtual reality platform was applied in environmental chemistry education to conduct a field trip to an overseas site, thus reducing the associated costs and environmental impacts that would have been associated with an RFT. The VFT field trip, thus, presents an environmentally friendly yet innovative approach to allow learning among students, while minimizing the related contributions to GHG emissions. Given the global push for environmental sustainability [20,21], it is anticipated that interest in VFTs will continue to increase in the future.

Recent research has proposed that the presence of VFTs, such as virtual laboratories, video visitations, and augmented reality laboratories can be an alternative to RFTs [22-25]. As compared to an RFT, the implementation of VFT provides flexibility to staff to perform high-quality research as an essential component of academic promotion and national/international recognition. In addition, VFTs appear to offer a more cost-effective way, which requires less support from faculty administration to deliver modulus, as compared to traditional fieldwork activities. It is important to note, however, that the assumption that VFTs may be as satisfactory, require less staff time, and are cheaper may be flawed, as they can take substantial time to prepare and produce, and investment in video production equipment may be required. Despite these limitations, VFTs allow for increased access, as more students can be accommodated in a safe and controlled environment. VFTs also promote flexibility, as students can access field opportunities at convenient times and locations without jeopardizing their ability to achieve comparable learning outcomes.

Proponents of RFTs argue that although VRTs can minimize the physical and psychological barriers to engagement and inclusion that students with disabilities face over RFT, it cannot completely replace the latter. Seifan, Dada, Berenjian, et al. [23] indicated that a VFT can only be a supplement, but not a replacement for an RFT, as it does provide the necessary pre-information and insight students need before visiting a real site. Particularly of importance is the effectiveness and usefulness of RFT on students' learning and perception. Teachers often discuss real-world examples in highly idealized terms during lectures. However, this type of information or even videos do not provide as in-depth experience as visiting a physical site. Additionally, classroom theories are usually explained with one correct answer, whilst decision-making in industry settings is fuzzy with lots of uncertainty and many possible answers, taking into account social, economic, and environmental issues. In an RFT, students have the opportunity to see and use specialized equipment, such as piling, ground anchor, and bridge construction, in a more real context. Apart from the educative aspect of field trips, a few studies that explored the relationships between experiential learning and career report that students' career development is sometimes invoked by exposure to real-life scenarios. Real field trips to construction workplaces allow students to interact with experts in the field, give them the privilege to connect classroom learning to real practical situations, and potentially increase their awareness of available career options, which could eventually influence their decisions and enhance interest and attitudes toward the profession associated with the workplace or sites visited [26]. Since field trips offer huge benefits, a well-designed field trip according to Beale [27] provides career guidance to students in the following ways:

"(1) it demonstrates the essentiality of work and how different kinds of work provide personal and societal benefits; (2) it acquaints students with local places of employment, thus allowing them to 
see the variety of settings and conditions in which work is performed; (3) it allows students to see how workers in various occupations use basic academic skills in their jobs; and (4) it helps students to understand the need for cooperation and teamwork in the production of goods and services".

While opportunities for interaction with professionals and career explorations provided by RFTs could be harnessed to cultivate the interest of students to pursue such careers, there is a paucity of studies examining the potential and influence of RFT on students' career development. Although a myriad of factors, such as chance events, can affect career hunting [28], students' perception of a certain profession, which can be partially gained through real fieldwork and site visits, can strongly influence career choice. As field experiences can enhance students' motivation and sense of construction activities, it is critical to plan effective site visits. Although much research has been devoted to the effect of virtual and real field trips on students' perception, less attention has been paid to the influence of real site visits on students' career aspirations. Due to the importance of RFTs as a pedagogical tool for deep learning, it is critical to assess their effectiveness on students' career development, as compared to other activities such as "virtual" field trips.

This study, therefore, endeavors to examine the usefulness of an educational site visit, along with hands-on experience on developing essential skills required for civil engineers' career aspirations. It also examines student perceptions on the use of VFT as part of their university experience and the extent to which it could replace RFTs. Specifically, the study sought to assess: (i) the effect of real site visit on understanding different aspects of the construction process; (ii) the effect of virtual/real site visits on students' perception; and (iii) the effect of construction site visits on students' career decision-making abilities.

\section{Research Methodology}

\subsection{Participants and Field Trip Location}

The target population in this study was undergraduate students at the University of Waikato. A total number of 50 students who enrolled in a second-year course (Highway and Transportation Engineering) participated in the pre- and post- site visit survey. The Waikato Expressway (Hamilton section) construction site was selected for the field trip as it consists of features being taught in lectures and is located near the university campus. As shown in Figure 1, the site is located east of Hamilton and construction is expected to be completed by 2020. During the trip, students were exposed to earthwork, piling, bridge construction, and penetration tests, among others.


Figure 1. (a) Geographical location of the construction site and (b) Waikato Expressway (Hamilton section, Mangaonua Stream Bridge) in New Zealand.

\subsection{Real Field Trip (Pre-Test and Post-Test)}

To investigate the objectives of this study, two anonymous surveys, namely pre- and post-site visit, were designed. The pre-site visit survey was distributed to all students before the field trip, while the post-site visit survey was done after. The students were asked to indicate their level of agreement 
with the first 12 statements presented in Table 1. These quantitative statements were scored based on a 5-point Likert-type scale, as follows: $1=$ strongly disagree, $2=$ disagree, $3=$ unsure, $4=$ agree, and $5=$ strongly agree. The students were then asked to convey their experience regarding statements 13-16, which were prepared in the form of multiple choice, binary questions of "Yes" or "No" and descriptive forms (Statements 13 and 15 were quantitative, while questions 14 and 16 were qualitative). In addition, an open-ended question was included in the surveys to obtain qualitative information regarding the advantages and barriers they noticed during the site visit as well as their thoughts on choosing their future careers solely by watching videos on civil engineering.

Table 1. Student survey statements.

\begin{tabular}{|c|c|c|c|}
\hline No. & Pre-Test Statements & No. & Post-Test Statements \\
\hline 1 & $\begin{array}{c}\text { A real site visit can increase my interest in } \\
\text { Highway and Transportation. }\end{array}$ & 1 & $\begin{array}{c}\text { A real site visit increased my interest in } \\
\text { learning more about Highway and } \\
\text { Transportation. }\end{array}$ \\
\hline 2 & $\begin{array}{c}\text { I prefer to watch a virtual site visit (e.g., } \\
\text { video) rather than visit a real construction } \\
\text { site. }\end{array}$ & 2 & $\begin{array}{l}\text { I prefer to watch a virtual site visit (e.g., } \\
\text { video) rather than go to a real } \\
\text { construction site. }\end{array}$ \\
\hline 3 & $\begin{array}{l}\text { Watching videos provides the same sort } \\
\text { of information as visiting a real } \\
\text { construction site. }\end{array}$ & 3 & $\begin{array}{c}\text { Watching videos provides the same sort } \\
\text { of information as visiting a real } \\
\text { construction site. }\end{array}$ \\
\hline 4 & $\begin{array}{l}\text { Watching videos gives me an idea of the } \\
\text { scale of machinery, earthworks, etc. at a } \\
\text { real construction site. }\end{array}$ & 4 & $\begin{array}{l}\text { Watching videos gives me an idea of the } \\
\text { scale of machinery, earthworks, etc. at a } \\
\text { real construction site. }\end{array}$ \\
\hline 5 & $\begin{array}{l}\text { Taking the Highway and Transportation } \\
\text { course without a real site visit enables me } \\
\text { to think creatively and innovatively. }\end{array}$ & 5 & $\begin{array}{l}\text { Taking the Highway and Transportation } \\
\text { course with a real site visit enabled me to } \\
\text { think creatively and innovatively. }\end{array}$ \\
\hline 6 & $\begin{array}{l}\text { Taking the Highway and Transportation } \\
\text { course without a real site visit enables me } \\
\text { to identify and solve practical problems. }\end{array}$ & 6 & $\begin{array}{l}\text { Taking the Highway and Transportation } \\
\text { course with a real site visit enabled me to } \\
\text { identify and solve practical problems. }\end{array}$ \\
\hline 7 & $\begin{array}{l}\text { Taking the Highway and Transportation } \\
\text { course without a real site visit enables me } \\
\text { to work as a part of a team. }\end{array}$ & 7 & $\begin{array}{l}\text { Taking the Highway and Transportation } \\
\text { course without a real site visit enabled me } \\
\text { to work as a part of a team. }\end{array}$ \\
\hline & I prefer to take the Highway and & & I prefer to take the Highway and \\
\hline 8 & $\begin{array}{c}\text { Transportation course without a real } \\
\text { site visit. }\end{array}$ & 8 & $\begin{array}{c}\text { Transportation course without a real } \\
\text { site visit. }\end{array}$ \\
\hline 9 & $\begin{array}{l}\text { I can understand most aspects of } \\
\text { Highway and Transportation just by } \\
\text { watching a video. }\end{array}$ & 9 & $\begin{array}{l}\text { I can understand most aspects of } \\
\text { Highway and Transportation just by } \\
\text { going to a real highway construction site. }\end{array}$ \\
\hline 10 & $\begin{array}{l}\text { I easily get lost when watching a video on } \\
\text { Highway and Transportation. }\end{array}$ & 10 & $\begin{array}{l}\text { I got lost at the real highway } \\
\text { construction site. }\end{array}$ \\
\hline 11 & $\begin{array}{l}\text { Watching a video enhances my learning } \\
\text { and gives me insight on implementing } \\
\text { theory in a specialized civil } \\
\text { engineering practice. }\end{array}$ & 11 & $\begin{array}{l}\text { Going to a real highway construction site } \\
\text { enhanced my learning and gave me an } \\
\text { insight on implementing theory in a } \\
\text { specialized civil engineering practice. }\end{array}$ \\
\hline 12 & $\begin{array}{l}\text { The lecture materials are sufficient to } \\
\text { understand different aspects of Highways } \\
\text { and Transportation. }\end{array}$ & 12 & $\begin{array}{c}\text { Attending a highway construction site is } \\
\text { essential in supplementing } \\
\text { lecture materials. }\end{array}$ \\
\hline 13 & $\begin{array}{l}\text { I think the approaches mentioned below } \\
\text { can enhance my understanding on } \\
\text { Highway and Transportation. }\end{array}$ & 13 & $\begin{array}{l}\text { After visiting the highway construction } \\
\text { site, I believe the learning approaches } \\
\text { mentioned below can enhance my } \\
\text { understanding on Highway and } \\
\text { Transportation. }\end{array}$ \\
\hline 14 & $\begin{array}{c}\text { Do you think you can be motivated } \\
\text { enough to choose your future career } \\
\text { discipline just by watching videos on civil } \\
\text { engineering? }\end{array}$ & 14 & $\begin{array}{c}\text { Do you think going to a real highway } \\
\text { construction site was motivating enough } \\
\text { to make you choose civil engineering as } \\
\text { your future career discipline? }\end{array}$ \\
\hline
\end{tabular}


Table 1. Cont.

\begin{tabular}{|c|c|c|c|}
\hline No. & Pre-Test Statements & No. & Post-Test Statements \\
\hline 15 & $\begin{array}{l}\text { As a civil engineer, I prefer to work in the } \\
\text { following disciplines. }\end{array}$ & 15 & $\begin{array}{l}\text { As a civil engineer, I prefer to work in the } \\
\text { following disciplines. } \\
\text { How would you rate the real highway } \\
\text { construction visit in helping you gain } \\
\text { industrial insight and self-esteem in } \\
\text { designing a highway (from } 0 \text { to } 8 \text { )? }\end{array}$ \\
\hline
\end{tabular}

\subsection{Data Analysis}

A survey instrument was used to obtain the research information and the collected data were quantitatively analyzed using IBM SPSS statistics package (v.24) (IBM Corporation, Chicago, IL, USA, 2019). A paired sample t-test was performed to determine the effects of a construction field trip on statements 1-12 and the $p$-value for statistical significance was defined as $p$-value $<0.05$. The open-ended questions were analyzed using a content analysis approach with NVivo 12 Pro software.

\section{Results}

\subsection{Effect of Real Site Visit on Understanding Different Aspects of the Construction Process}

Site visits are an integral part of the Highway and Transportation curricula, as they significantly contribute to understanding complex project-specific limitations and constraints that students might be exposed to in an engineering career. Statements 1-8 aim at getting students to score the effects of site visits on understanding the aspects of construction processes taught in the Highway and Transportation course. As shown in Figure 2, the responses to statement did not significantly change after the site visit and the students, on average, agreed on the significance of real site visits in increasing their interest in learning more about the Highway and Transportation course. The students were asked to compare the effectiveness of virtual and real site visits. Statistically, the responses to Statements 2-6 in the pre-site visit survey were significantly different from that of the post-site visit. Students' preferences on watching a virtual site visit decreased significantly ( $p$-value $<0.05$ ) after going to a real construction site. The students had significantly different votes for information they can acquire on construction processes before and after the visit. In the pre-site visit survey, more than $58 \%$ of the students scored (>3) - watching a VFT provides the same sort of information as visiting a real construction site-while this level of agreement was seen in only $21 \%$ of the students in the post-site evaluation. As compared to the post-site visit, there was a greater diversity of opinion regarding the learning that can be achieved by watching videos as a virtual site visit before attending the field trip (Statement 3). A similar observation was also recorded for statement 4 , where only $28 \%$ of the students disagreed/strongly disagreed that VFT gave them an idea about the scale of machinery, earthworks, etc. in the pre-site visit survey, whereas this level of disagreement significantly increased to $61 \%$ in the post-site visit survey. The survey study also indicated that taking the Highway and Transportation course with a real site visit can significantly enable them to not only think creatively and innovatively, but also identify and solve practical problems, as compared to having the course without such a site visit (Statements 5 and 6). The effects of a real construction site visit on collaborative skills were also investigated. In the pre-site visit evaluation, the students were, on average, unsure about the influence of site visit on teamwork skills, while the opinion significantly changed after going to a construction site- they disagreed that taking a course without a real site visit can enable them to work as a part of a team in a civil engineering discipline. On the whole, the students' attitude towards taking the Highway and Transportation course without a real site visit did not change significantly ( $p$-value $>0.05$ ) after visiting the construction site, where they scored an average value of 2.22 and 2.10 for the pre- and post-site visit surveys, respectively (Statement 8 ). 


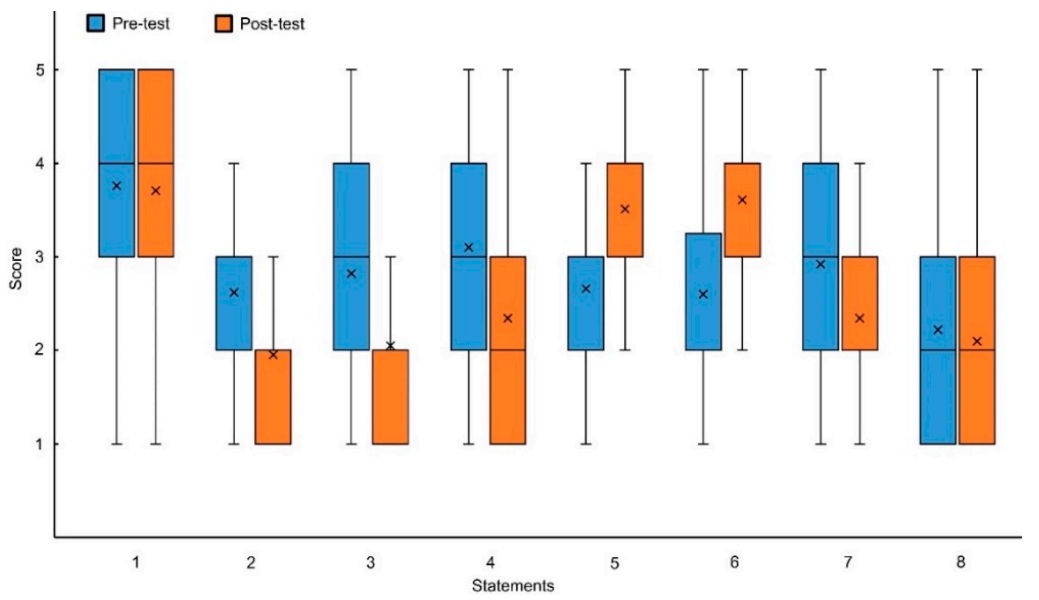

Figure 2. Students' responses to Statements $1-8(1=$ strongly disagree, $2=$ disagree, $3=$ unsure, $4=$ agree and $5=$ strongly agree).

\subsection{The Effects of Virtual/Real Site Visit on Students' Perception}

As shown in Figure 3a, the students' responses in the pre-site visit evaluation on understanding construction aspects via only watching videos were significantly different $(p$-value $<0.05)$ from that of the post-site visit survey. In terms of processes taking place in a construction site, students scored 2.98 when they were asked to indicate the ease of following processes when watching related videos (Figure 3b). However, their opinions were significantly different in the post-site visit survey, where they mostly disagreed on getting lost in construction processes when they visit a real site. As shown in Figure $3 c$, there was no statistically significant $(p$-value $>0.05$ ) difference between the student's responses on gaining industrial insight to implement theory in civil engineering practice by watching a VFT or a real site visit. The students, on average, agreed (3.71) in the post-site visit evaluation that a site visit is an essential supplement to lectures, while in the pre-site survey, they were unsure (2.84) as to whether the lecture materials were sufficient to understand different aspects of the Highway and Transportation course or not.

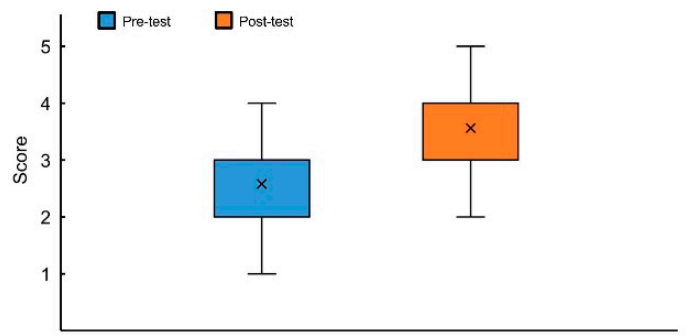

(a)

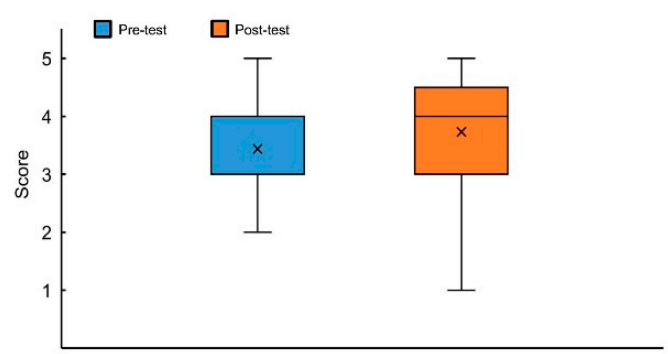

(c)

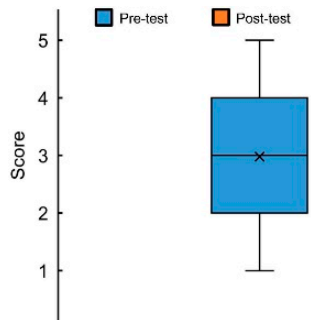

(b)

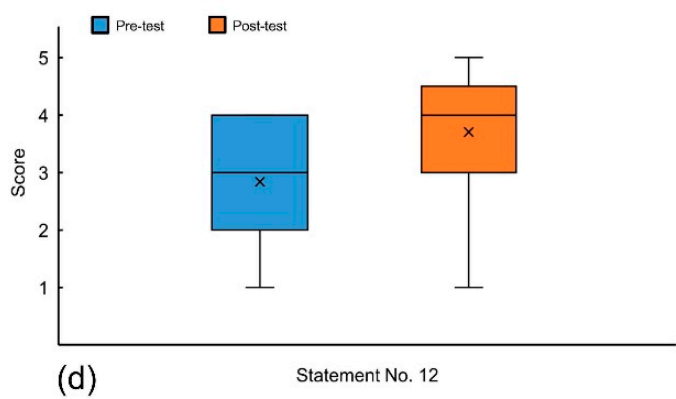

Figure 3. Students' responses to Statements (a) No. 9, (b) No. 10, (a) No. 11 and (d) No. 12 (1 = strongly disagree, 2 = disagree, $3=$ unsure, $4=$ agree and $5=$ strongly agree). 


\subsection{The Effectiveness of Teaching Components}

Teaching components play an important role in providing an efficient learning environment. The presence of ideal teaching components in a curriculum can strengthen problem-solving, goal setting, self-awareness, and self-management skills. To identify the usefulness of teaching components on understanding the Highway and Transportation course, the students were asked to choose the most effective components (watching videos, lectures, and site visits) in both the pre- and post-site visit surveys. According to Figure 4, in the pre-site evaluation, students ranked important teaching components-real site visits (38\%), lectures $(24 \%)$, and watching videos $(27 \%)$ related to the topic. A similar trend was recorded in the post-site visit survey, where students scored the real site visit as the most effective teaching component. In both cases, the lowest scores were associated with watching videos. Interestingly, a similar percentage (34\%) for the usefulness of lectures in understanding the course was noted in both the pre- and post-site visit surveys. However, students gave watching videos a higher percentage before attending a real construction site. In contrast, students found the real site visit more effective, indicating that a field trip can enhance learning.

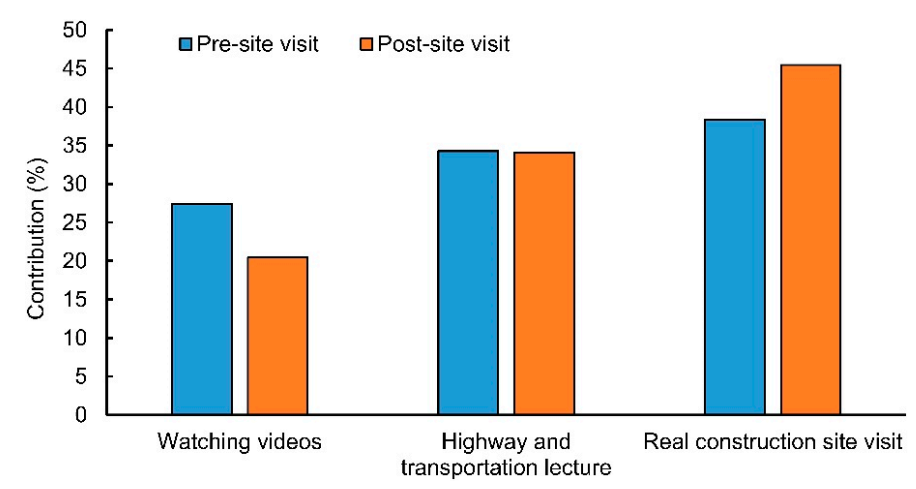

Figure 4. Students' responses on the effectiveness of teaching components (Statement 13).

\subsection{Effect of Construction Site Visit on Students' Career Decision-Making}

To date, extensive resources have been devoted to identifying the potential ways to steer students into engineering careers. Among them, site visits to introduce students to a real-world application of engineering topics have been recognized as an attractive and effective way. In this section, the results obtained from students regarding the effect of real and virtual site visits on career-related decision-making are presented. As demonstrated in Figure 5a, the survey data reveals that only $14 \%$ of students were motivated enough to choose their future career discipline by watching site visitation videos. This indicates that virtual site visits were not attractive enough to convince students to pursue a civil engineering career. On the other hand, $59 \%$ of the students reported that real site visits could motivate their choice of civil engineering as a future career discipline (Figure $5 b$ ).

(a)

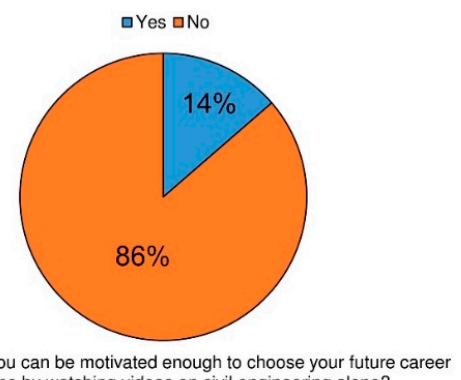

Do you think you can be motivated enough to choose your future career discipline by watching videos on civil engineering alone? (b)

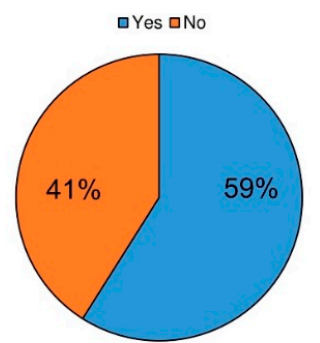

Do you think going to the real highway construction site was motivating enough to choose your future career discipline on civil engineering?

Figure 5. Students' responses on the effect of (a) virtual field trip and (b) real field trip on choosing a career path (Statement 14). 
One observation that came out quite clearly from the accompanying comments of survey participants with regards to Figure 5 above, as depicted in Figure 6, is the word "Experience". The students mentioned that they would be motivated enough to choose their future if they experienced it themselves rather than watching videos on it. About $85 \%$ of the written accompanying comments to Statement 14 alluded to this. Some excerpts are:

"Watching videos does not give me the full experience as I site visit would do." (Student 3)

"You don't a get a good sense of scale or proper experience from watching a video." (Student 19)

"Exposure to construction site is critical to understand job-related challenge." (Student 11)

"I am more likely to be motivated by hearing other people talk about their own experiences and their opinions of the field rather than a video." (Student 17)

“Because a video won't provide actual experience. Can't know whether the person who made the video really has much experience in the field you want to study. Need actual interactions and a person in the industry to show you and explain. A video can't answer questions." (Student 14)

This clearly indicates that the inclusion of real site visits in curriculums can help students to take up professional careers mainly by providing students with real experiences and exposure to a range of engineering responsibilities [29].

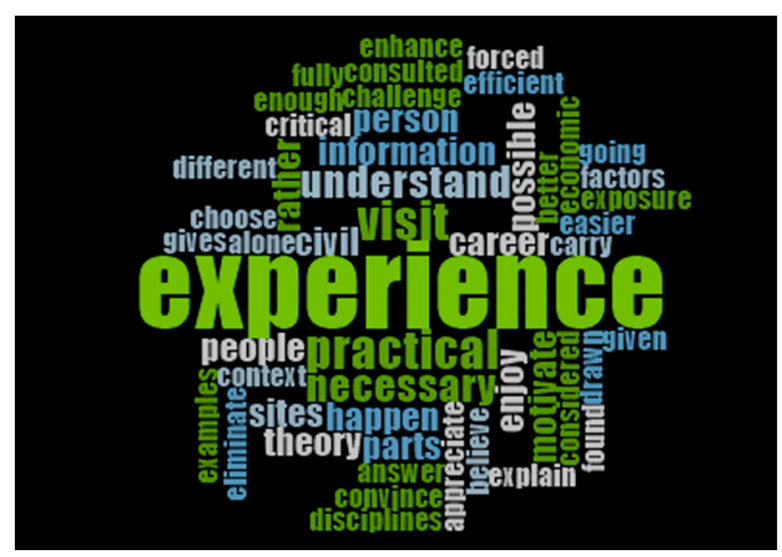

Figure 6. Students' responses to Statement 14.

The students were also asked to indicate their career preference based on watching VFT and observing real construction sites. The career preferences were structural, construction, geotechnical, transportation, earthquake, surveying, water resources, environmental, municipal, and coastal engineering. Figure 7 illustrates a detailed profile of disciplines selected by students before and after attending the field trip. In the pre-test survey, structural engineering was the most popular discipline $(32 \%)$, followed by construction $(22 \%)$, geotechnical $(11 \%)$, and transportation $(10 \%)$ engineering. However, after visiting the construction site, the student's interests to work in construction and transportation engineering increased to $25 \%$ and $12 \%$, respectively. This shows that construction sites could influence career choice. In contrast, the students' interest to work as structural engineers decreased by $5 \%$ after visiting the construction site. The percentage for the other disciplines, including earthquake, surveying, water resources, environmental, municipal, and coastal engineering, remained unchanged $(25 \%)$ after the site visit. 


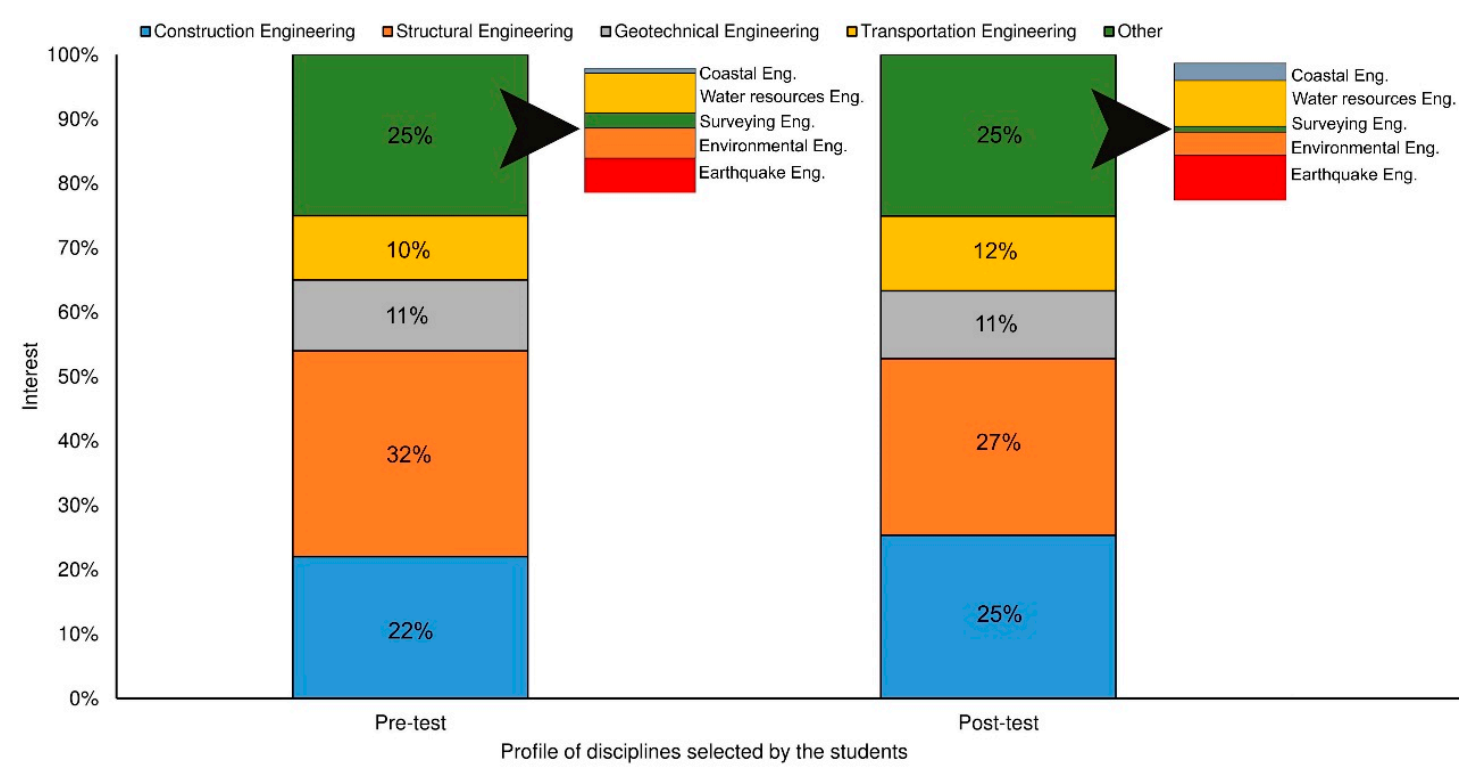

Figure 7. The profile of disciplines selected by students before and after visiting the construction site (Statement 15).

At the end of the survey, the students were asked to include their opinions about the positive and negative aspects of site visits; the selected comments are given in Table 2. From the students' point of view, exposure to construction processes and job-related challenges, along with talking to experts in the field, were among the positive aspects of the site visit. In addition, they reported that the visit helped them gain a better insight into the process and machinery scale. Some of them indicated that the visit supported their decision regarding choice of career. On the other hand, students identified five barriers that decreased the efficiency of the site visit. The challenges were mainly due to time and the number of attendees at the site visit. The lack of comprehensive explanation on the different roles of engineers in the construction site as a result of time restriction was another negative aspect pointed out by the students.

Table 2. Selected students' responses on the advantages and barriers of the site visit.

\begin{tabular}{cc}
\hline Aspects the Students Liked Most about the Field Trip & Aspects the Students Disliked about the Field Trip \\
\hline $\begin{array}{c}\text { Real-life experience helped to see what we enjoy doing } \\
\text { and what we do not. }\end{array}$ & $\begin{array}{c}\text { Too lengthy visit } \\
\text { Exposure to job-related challenges }\end{array}$ \\
$\begin{array}{c}\text { Wistening to experts talk about their own experiences } \\
\text { and opinions. }\end{array}$ & $\begin{array}{c}\text { Very large groups } \\
\text { Good sense of scale }\end{array}$ \\
$\begin{array}{c}\text { Nite visit definitely supported my decision regarding my pre-information } \\
\text { career choice }\end{array}$ & $\begin{array}{c}\text { The different roles of the engineers were not } \\
\text { explained explicitly at the construction site }\end{array}$ \\
\hline
\end{tabular}

\section{Discussion}

Mills, Ashford and McLaughlin [30] described a construction-related course as a laboratory of the real-world, supported by the application of contemporary theory. Although many educational tools have been introduced to enhance teaching practices, challenges remain in effective teaching construction-related courses. The provision of site-based experiences has been reported as a powerful supplement to lectures. However, the difficulties in performing site visits significantly curtails the usefulness of such an activity. If ideally performed, a construction site visit or in general an RFT is a valuable experience for students who can visualize a construction environment and real-world practices. Three main factors have been identified for successful construction education, namely (i) 
constant exposure to the latest industry practices; (ii) awareness of the latest technology used in the field; and (iii) availability of scholars to apply the contemporary theory to current industry situations [30]. These are indicatives of the importance of experience-based learning in construction-related courses. In experience-based learning, knowledge results from a combination of grasping and transforming experiences; a key element of which is that the learners analyze their experience by reflecting, evaluating, and reconstructing it [31]. As indicated in previous research [32], the contextual understanding of problem(s) is a critical step in the learning process. It was found that real site visits provide a first-hand exposure to identifying and understanding the complexities of a construction process and the issues that might arise during construction. Moreover, site visits provide students with the opportunity to directly communicate with a professional engineer involved in a construction project. Additionally, it exposes them to multiple spatiotemporal conditions, provides the chance to acquire more in-depth insight into theoretical concepts, and help them to apply those concepts in real-world problems [12]. Results from this study suggest that the lack of pre-knowledge can decrease the effectiveness of a site visit. Prior to RFT, the incorporation of virtual site visits [33,34] can substantially provide pre-knowledge to enhance experience-based learning. However, it is not possible to know if the person who made the VFT really has much experience in the field. In such cases, the effectiveness of VFT decreases.

Apart from the usefulness of site visit on learning, this study has shown that RFTs can significantly help students improve their career self-efficacy and career-related skills. These findings align with previous studies [35]. It has been noted that appropriate career preferences are important, not only for individuals, but also for the society as a whole [36]. Tang, Pan and Newmeyer [37] proposed a conceptual model to explain students' career aspirations. Based on the proposed model, learning experiences can affect career self-efficacy and expectation outcomes. These two factors can influence career interests and, consequently, career choice. Although it has been reported that learning experiences from real-world examples and self-efficacy are two critical factors influencing students' career development, other factors such as contextual and personal attributes may also affect career choice [37]. The results of this study indicate that the integration of a high-quality site visit can significantly help student shape their career interests and choices. However, to be more efficient, it is important to re-structure the curriculum to make it more stimulating and to keep the course components well integrated. For example, the comments by students regarding the negative aspects of site visits indicate that the visits need to better organized and re-structured to be in conjunction with the lectures.

In line with the findings of Fries, Oliver, Quak, et al. [9], results from our study suggest that an integrated approach consisting of both VFTs and RFTs are more effective in achieving students' learning outcomes. An integrated approach to teaching involving the use of both virtual and real-field trips promotes a social constructivism method of learning, as it affords students the opportunity to make connections between what is taught in class and their experiences outside. Furthermore, the view reflected in this study that VFTs may not entirely replace traditional field trips align with previous studies [13]. It is advocated that VFT could be treated as an 'experiment', rather than a 'solution'. However, because of the limitations associated with organizing RFTs, there might be the need for teachers and facilitators to support RFTs with innovative virtual activities, in line with the pedagogical objectives of the RFT centering around encouraging students' critical and reflective thinking. This finding supports the work of Azlina, Amin and Lukito, et al. [38], where field-independent students demonstrated higher levels of creativity than their field-dependent counterparts.

From a sustainability perspective, one may argue that the approach of integrating virtual and real field trips into learning programs for students can reduce carbon emissions and environmental pollution by reductions in fossil fuel consumption, which would have otherwise been associated with RFTs alone. Futuristically, however, it may be important to consider studies on students' self-reported perception on the impact that an integrated virtual and real field trips learning approach may have in terms of contribution to climate change and/or reducing environmental pollution. This is in line with recent efforts [39] to train students to create VFTs as a means of narrating their own place-based stories 
regarding the United Nations Sustainable Development Goals (SDGs) in a way that motivates global youth action to protect the environment.

\section{Conclusions}

Two major conclusions emerge from this study. First, students perceive VFT as an interesting way to learn and are excited by the possibilities facilitated by this new technology. However, findings from this study show that the students were in complete agreement that VFT was not a replacement for RFT. Clearly, while the students welcome the use of a VFT as part of their engineering undergraduate experience, they did not entirely suggest that it replace field courses. Secondly, many of the students agreed that they could be motivated to choose their career by going on real field trips, as compared to virtual ones. This emphasizes the influence a well-planned RFT could have on students' future career aspirations, and it should be well thought through and planned in order to benefit the students. From a holistic perspective, the issue is not whether VFTs can replace traditional field trips or not, but instead on steps to be taken to create a social constructivism approach of lectures, and virtual and real-field trips, which gives students the opportunity to make multiple links between what is being taught in the classroom and their experiences in the real world outside the classroom.

Author Contributions: Conceptualization, M.S. and A.B.; methodology, M.S. and O.D.D.; formal analysis, M.S.; writing - original draft preparation, M.S.; writing—review and editing, A.B. and O.D.D.; funding acquisition, M.S. All authors have read and agreed to the published version of the manuscript.

Funding: This research was funded by the University of Waikato, Hamilton, New Zealand.

Acknowledgments: The authors would like to thank the students of the Highways and Transportation class at The University of Waikato, New Zealand, for their active participation in this research work. The authors would also like to thank NZ Transport Agency and Simon Brandon for facilitating the site visit.

Conflicts of Interest: The authors declare no conflict of interest.

\section{References}

1. Paez, D.; Rubio, L.A. The Use of Field Trips in the Context of Engineering Collaborative Teaching Experiences of Hands-On Geomatics Activities in Colombia. Available online: https://www.fig.net/resources/ proceedings/fig_proceedings/fig2015/papers/ts04f/TS04F_paez_rubio_7484.pdf (accessed on 5 February 2020).

2. Prince, M. Does active learning work? A review of the research. J. Eng. Educ. 2004, 93, 223-231. [CrossRef]

3. Preszler, R.W. Replacing lecture with peer-led workshops improves student learning. CBE Life Sci. Educ. 2009, 8, 182-192. [CrossRef]

4. Bligh, D.A. What's the Use of Lectures? Intellect Books: England, UK, 1998.

5. Bradbury, N.A. Attention span during lectures: 8 seconds, 10 minutes, or more? AJP Adv. Physiol. Educ. 2016, 40, 509-513. [CrossRef]

6. Bray, C.J.E.E.R. Program evaluation of the sustainability of teaching methods. Environ. Educ. Res. 2008, 14, 655-666. [CrossRef]

7. Walker, J.; Cotner, S.H.; Baepler, P.M.; Decker, M.D. A delicate balance: Integrating active learning into a large lecture course. CBE Life Sci. Educ. 2008, 7, 361-367. [CrossRef]

8. Armstrong, N.; Chang, S.-M.; Brickman, M. Cooperative learning in industrial-sized biology classes. CBE Life Sci. Educ. 2007, 6, 163-171. [CrossRef]

9. Friess, D.A.; Oliver, G.J.; Quak, M.S.; Lau, A.Y. Incorporating "virtual" and "real world" field trips into introductory geography modules. J. Geogr. High. Educ. 2016, 40, 546-564. [CrossRef]

10. Day, T. Undergraduate teaching and learning in physical geography. Prog. Phys. Geogr. 2012, 36, $305-332$. [CrossRef]

11. Leydon, J.; Turner, S. The challenges and rewards of introducing field trips into a large introductory geography class. J. Geogr. 2013, 112, 248-261. [CrossRef]

12. Eiris Pereira, R.; Gheisari, M. Site Visit Application in Construction Education: A Descriptive Study of Faculty Members. Int. J. Constr. Educ. Res. 2017. [CrossRef]

13. Spicer, J.I.; Stratford, J. Student perceptions of a virtual field trip to replace a real field trip. J. Comput. Assist. Learn. 2001, 17, 345-354. [CrossRef] 
14. Mead, C.; Buxner, S.; Bruce, G.; Taylor, W.; Semken, S.; Anbar, A.D. Immersive, interactive virtual field trips promote science learning. J. Geosci. Educ. 2019, 67, 131-142. [CrossRef]

15. Argles, T.; Burden, D.; Tilling, S.; Minocha, S. FieldscapesVR: Virtual World Field Trips to Extend and Enrich Field Teaching. Available online: https://www.americangeosciences.org/sites/default/files/igc/2109.pdf (accessed on 6 February 2020).

16. Pham, H.C.; Dao, N.-N.; Pedro, A.; Le, Q.T.; Hussain, R.; Cho, S.; Park, C. Virtual field trip for mobile construction safety education using 360-degree panoramic virtual reality. Int. J. Eng. Educ. 2018, 34, 1174-1191.

17. Jacobson, A.R.; Militello, R.; Baveye, P.C. Development of computer-assisted virtual field trips to support multidisciplinary learning. Comput. Educ. 2009, 52, 571-580. [CrossRef]

18. Jolley, A.; Kennedy, B.; Reyna, N.; Stahl, T.; Hampton, S.; Sommerville, P.; Wilson, T.; Brogt, E.; Pedley, K.; Davidson, J. Virtual Field trips in tertiary science. 2018.

19. Fung, F.M.; Choo, W.Y.; Ardisara, A.; Zimmermann, C.D.; Watts, S.; Koscielniak, T.; Blanc, E.; Coumoul, X.; Dumke, R. Applying A Virtual Reality Platform in Environmental Chemistry Education to Conduct A Field Trip to An Overseas Site; ACS Publications: Washington, DC, USA, 2019.

20. Finger, M.; Serafimova, T. Internalising the external costs of transport. 2019.

21. Salvucci, R.; Tattini, J. Global Outlook for the Transport Sector in Energy Scenarios. In DTU International Energy Report 2019: Transforming Urban Mobility; DTU: Lyngby, Denmark, 2019; pp. 21-27.

22. Domínguez, J.C.; Miranda, R.; González, E.J.; Oliet, M.; Alonso, M.V. A virtual lab as a complement to traditional hands-on labs: Characterization of an alkaline electrolyzer for hydrogen production. Educ. Chem. Eng. 2018, 23, 7-17. [CrossRef]

23. Seifan, M.; Dada, D.; Berenjian, A. The effect of virtual field trip as an introductory tool for an engineering real field trip. Educ. Chem. Eng. 2018. [CrossRef]

24. Hehr, K.H. Virtual Field Trips as an Educational and Motivational Strategy to Teach Iowa History. Available online: https://ib.dr.iastate.edu/cgi/viewcontent.cgi?article=5185\&context=etd (accessed on 6 February 2020).

25. Placing, K.; Fernandez, A. Virtual experiences for secondary science teaching. Aust. Sci. Teach. J. 2002, 48, 40.

26. Elleven, R.; Wircenski, M.; Wircenski, J.; Nimon, K. Curriculum-based Virtual Field Trips: Career Development Opportunities for Students with Disabilities. Available online: https://files.eric.ed.gov/fulltext/EJ854371.pdf (accessed on 6 February 2020).

27. Beale, A.V. Elementary school career awareness: A visit to a hospital. J. Career Dev. 2000, 27, 65-72. [CrossRef]

28. Bubany, S.T.; Krieshok, T.S.; Black, M.D.; McKay, R.A. College students' perspectives on their career decision making. J. Career Assess. 2008, 16, 177-197. [CrossRef]

29. Lichtenstein, G.; Loshbaugh, H.G.; Claar, B.; Chen, H.L.; Jackson, K.; Sheppard, S.D. An engineering major does not (necessarily) an engineer make: Career decision making among undergraduate engineering majors. J. Eng. Educ. 2009, 98, 227-234. [CrossRef]

30. Mills, A.; Ashford, P.; McLaughlin, P. The Value of Experiential Learning for Providing a Contextual Understanding of the Construction Process. Available online: https://dro.deakin.edu.au/eserv/DU:30037064/ mills-valueofexperiential-2006.pdf (accessed on 6 February 2020).

31. Gruszka, K.; Rammel, C. Science-Society Interfaces-Transforming Universities. In Engaging Stakeholders in Education for Sustainable Development at University Level; Springer: Berlin, Germany, 2016; pp. 177-189.

32. Ramsden, P. Context and Strategy. In Learning Strategies and Learning Styles; Springer: Berlin, Germany, 1988; pp. 159-184.

33. Yang, K.Y.; Heh, J.S. The impact of internet virtual physics laboratory instruction on the achievement in physics, science process skills and computer attitudes of 10th-grade students. J. Sci. Educ. Technol. 2007, 16, 451-461. [CrossRef]

34. Brown, A.; Green, T. Virtual reality: Low-cost tools and resources for the classroom. TechTrends 2016, 60, 517-519. [CrossRef]

35. Burns, C.; Chopra, S. A meta-analysis of the effect of industry engagement on student learning in undergraduate programs. J. Technol. Manag. Appl. Eng. 2017, 33, 1-20.

36. Pekkaya, M. Career Preference of University Students: An Application of MCDM Methods. Procedia Econ. Financ. 2015, 23, 249-255. [CrossRef] 
37. Tang, M.; Pan, W.; Newmeyer, M.D. Factors influencing high school students' career aspirations. Prof. Sch. Couns. 2008, 11, 285-295. [CrossRef]

38. Azlina, N.; Amin, S.; Lukito, A. Creativity of Field-dependent and Field-independent Students in Posing Mathematical Problems. Available online: https://iopscience.iop.org/article/10.1088/1742-6596/947/1/012031 (accessed on 6 February 2020).

39. Arizona State University. Sustainability News: Inspiring Sustainability action through Virtual Field Trips. Available online: https://sustainability.asu.edu/news/archive/inspiring-sustainability-action-through-virtualfield-trips/ (accessed on 2 February 2020).

(C) 2020 by the authors. Licensee MDPI, Basel, Switzerland. This article is an open access article distributed under the terms and conditions of the Creative Commons Attribution (CC BY) license (http://creativecommons.org/licenses/by/4.0/). 